\title{
Antagonistic microorganisms and nitrogen fertilization in control of tomato southern blight
}

\author{
Neder Henrique Martinez Blanco ${ }^{1}$ (D) https://orcid.org/0000-0002-6786-5493 \\ Danilo Ferreira Ramirez Barbosa² (D) https://orcid.org/0000-0002-8299-2933 \\ Felipe André Sganzerla Graichen²* (D) https://orcid.org/0000-0003-0516-5042 \\ 1. Universidade Estadual do Mato Grosso do Sul/Programa de Pós-Graduação em Agronomia/Aquidauana (MS), Brasil \\ 2. Universidade Estadual do Mato Grosso do Sul/Laboratório de Fitossanidade/Aquidauana (MS), Brasil \\ *Corresponding author: f_graichen@yahoo.com.br
}

\begin{abstract}
The present study assessed the efficacy of formulated biocontrol agents and nitrogen fertilization on southern blight control. Antagonism test in vitro was performed to assess the inhibitory activity of Bacillus methylotrophicus and Trichoderma asperellum against the growth of Sclerotium rolfsii. Tomato seedlings were transplanted into the substrate added with ammonium nitrate doses and inoculated with the formulated biocontrol agents Ônix (B. methylotrophicus) or Quality (T. asperellum). Subsequently, seedlings were inoculated with S. rolfsii. Plant mortality, shoot and root weight were assessed 11 days after the last inoculation. Agents had effective inhibitory activity against S. rolfsii; thus, they could reduce southern blight severity when combined with ammonium nitrate. However, plant mortality was not reduced by them.
\end{abstract}

Keywords: Bacillus methylotrophicus; Sclerotium rolfsii; Solanum lycopersicum; Trichoderma asperellum; ammonium nitrate.

\section{INTRODUCTION}

Sclerotium rolfsii, the pathogen of southern blight, causes root and crown rot, wilt and damping off in plants. This fungus can infect over 500 plant species due to its low host specificity (PUNJA, 1985).

Sclerotium rolfsii colonizes crop residues and produces sclerotium (resistance mechanism) to survive environmental extremes, such as lack of food sources for long periods-of-time (BENÍTEZ et al., 2004). The sclerotium of S. rolfsii has a melanized outer layer, cortex and a medulla consisting of thread-like hyphae. It is round-shaped and its size ranges from 0.5 to $3 \mathrm{~mm}$ in diameter. The secretion of oxalic acid triggers the infectious process and reacts to calcium in the cell wall, which first produces calcium oxalate, then the pathogen secrets pectinase and endopolygalacturonase (enzymes). Therefore, it enables plant tissue penetration by fungal mycelium (PUNJA, 1985; SARMA et al., 2002; SERRA; SILVA, 2005).

Southern blight is difficult to manage due to the low efficiency of the chemical control (RISTAINO et al., 1991; ROSE et al., 2003) and the low host specificity of its pathogen impairs the adoption of appropriate crop rotation and using genetic resistance (PUNJA, 1985). Soil fertility (GHINI, et al., 2001) and inoculation with antagonistic biocontrol agents (BROŽOVÁ, 2004; MORETINI; MELO, 2007) are alternatives to southern blight management.

Soil fertility helps to suppress soilborne pathogens. Nitrogen may be associated with disease severity mitigation in plants, as it is a vital nutrient for their survival. Several nitrogen sources, such as ammonium nitrate, were effective in suppressing soilborne pathogens; consequently, nitrogen was able to minimize the severity of S. rolfsii (CRUZ et al., 2013; GHINI et al., 2001; MORI, 2015; PACHECO, 2012).

Biological control has been considered an alternative solution to plant disease management (BROŽOVÁ, 2004), since it has helped mitigating root disease severity (BARAKAT et al., 2005) - mainly when combined to crop management (DIMKIĆ et al., 2013). Trichoderma fungi and Bacillus are able to control southern blight due to their antimicrobial action against Sclerotium spp. (BONTEMPO, 2016; MCLEAN; STEWART, 2000; MELERO-VARA et al., 2000; PACHECO,

Received: Jun 19, 2019 Accepted: Oct 30, 2020

Associate Editor: Silvia Galleti

Peer Review History: Double-blind Peer Review. 
2012; VILLALTA et al., 2012). In addition, these microorganisms can be easily cultivated en masse (BONTEMPO, 2016) and have already been grown for commercial purposes. Therefore, the aim of this study was to assess the effectiveness of formulated biocontrol agents and nitrogen fertilization in southern blight management.

\section{MATERIAL AND METHODS}

Experiments were carried out in vitro and in vivo to assess the efficacy of antagonistic microorganisms and nitrogen fertilization in southern blight management. Experiments in vitro assessed the inhibitory activity of Bacillus methylotrophicus and Trichoderma asperellum against mycelial growth of $S$. rolfsii in culture medium. Experiments in vivo assessed the efficacy of antagonistic microorganisms amended with ammonium nitrate doses in reducing southern blight severity in tomato plants.

Isolated S. rolfsii was collected from bean plant roots (Phaseolus vulgaris L.) presenting damping off symptoms and

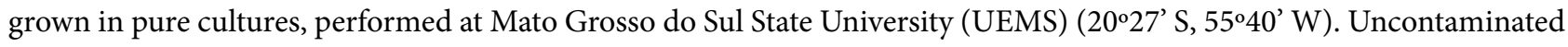
sclerotia were collected and stored in plastic microtubes at $4{ }^{\circ} \mathrm{C}$ for further use.

\section{Effect of biocontrol agents on S. rolfsii}

The inhibitory activity of B. methylotrophicus against $S$. rolfsii was assessed through the cross-streak method (FUGA et al., 2011). The microbial strain Ônix (Farroupilha Laboratory: Patos de Minas City, MG) (B. methylotrophicus 16 g.L L $^{-1}$ ) was selected for the experiment. Yeast extract-dextrose- $\mathrm{CaCO}_{3}$ (YDC) agar plates (CHUNG et al., 2015) were added with bacterial suspension $(0.5 \mathrm{~mL})$ and were incubated at $30 \pm 2{ }^{\circ} \mathrm{C}$ (PALOP et al., 1999) under a 12-hour photoperiod for $24 \mathrm{~h}$ (PACHECO, 2012). The bacterium was subsequently inoculated in potato-dextrose-agar (PDA) by a single streak in the center of the dish. Two mycelial pieces $(4 \times 4 \mathrm{~mm})$ were placed $1 \mathrm{~cm}$ apart from the edges of the plates and later grown in a biological oxygen demand (BOD) growth chamber at $27 \pm 2{ }^{\circ} \mathrm{C}$ under a 12-hour photoperiod for 2 days. Finally, the diameter of S. rolssii colonies was measured.

The efficacy in vitro of the inhibitory activity and the action of volatile and nonvolatile metabolites of T. asperellum against S. rolfsii were assessed using commercial biocontrol agent Quality (T. asperellum 280 g. $\mathrm{L}^{-1}$ ) (Farroupilha Laboratory: Patos de Minas City, MG), whose granules were washed and placed in PDA agar plates added with streptomycin sulfate (300 mg. $\mathrm{L}^{-1}$ ). The plates were incubated at $25 \pm 2{ }^{\circ} \mathrm{C}$ under a 12-hour photoperiod for 7 days (CARVALHO et al., 2014). Mycelial pieces were placed on the opposite end of PDA agar plates added with streptomycin sulfate $\left(300 \mathrm{mg} \cdot \mathrm{L}^{-1}\right)$ and arranged in parallel to the mycelial pieces. Colonies were measured 3 days after incubation at $25 \pm 2{ }^{\circ} \mathrm{C}$ under a 12 -hour photoperiod.

The assessment of nonvolatile metabolites was carried out based on agar disk diffusion method. First, a cellophane disc $(10 \mathrm{~cm}$ in diameter) was placed on the surface of PDA agar added with streptomycin sulfate (300 mg.L-1 $)$. A mycelial disc of T. asperellum fungus was placed in the center of the cellophane, incubated at $25 \pm 2{ }^{\circ} \mathrm{C}$ under a 12-hour photoperiod for 3 days, for growth and metabolite production purposes. The cellophane paper was discarded and the plate lid was disinfected by flaming to a Bunsen burner flame to reduce contamination. One mycelial disc of $S$. rolfsii was placed in the center of each agar plate, incubated at $25 \pm 2{ }^{\circ} \mathrm{C}$ under a 12-hour photoperiod. Incubation period ended when $S$. rolfsii had grown over the agar surface on plates without metabolites of T. asperellum. (DENNIS; WEBSTER, 1971; MARTINS-CORDER; MELO, 1998).

Trichoderma asperellum volatile metabolites antagonistic to S. rolfsii was assessed as follows: mycelial pieces of S. rolfsii and T. asperellum were individually placed in the center of PDA agar plates, which were separately incubated at $25 \pm 2{ }^{\circ} \mathrm{C}$ under a 12 -hour photoperiod for $24 \mathrm{~h}$. After incubation, the lid of the plates containing T. asperellum was replaced by the plates containing $S$. rolfsii. The two half-plates were taped together for later incubation, which kept on going until $S$. rolfsii colonies without volatile metabolites completely colonized the agar. The diameter of $S$. rolfsii colonies was measured (CARVALHO et al., 2014; DENNIS; WEBSTER, 1971).

Diameters of S. rolfsii colonies (DMsr) and their nonantagonistic controls $\left(\mathrm{DM}_{\mathrm{wB}}\right)$ were measured in all tests in vitro. Inhibition (expressed in percentage) was calculated through the following (Eq. 1):

$$
\text { \%Inhibition }=\left(\frac{\mathrm{DM}_{\mathrm{WB}}-\mathrm{DM}_{\mathrm{SR}}}{\mathrm{DM}_{\mathrm{WB}}}\right) \times 100
$$

Inhibition was graded based on the scale by BELL et al. (1982) (BARAKAT et al., 2005), which classifies five grades of antagonistic degrees: grade 1 is full control; grade 2 is $75 \%$ control; grade 3 is $50 \%$ control; grade 4 is up to $25 \%$ control; grade 5 is no control. Experiments in vitro followed a completely randomized design with 10 replications. Tests were seen as separate experiments. 


\section{Effect of biocontrol agents and ammonium nitrate on tomato southern blight}

Sclerotium rolfsii inoculum was prepared in polished rice, based on the method by SERRA; SILVA (2005), with modifications. Polished rice grains were immersed in distilled water for $2 \mathrm{~h}$ and sterilized in an autoclave. Subsequently, five mycelial pieces were inoculated in flasks added with $50 \mathrm{~g}$ of rice, incubated at $27 \pm 2{ }^{\circ} \mathrm{C}$ under a 12-hour photoperiod for 7 days.

Tomato seedlings (Solanum lycopersicum L. 'Santa Cruz Kada Gigante') were grown in a greenhouse using 128 cells polystyrene trays filled with Carolina substrate (Soil do Brasil). The seedlings were irrigated by micro sprinklers for $1 \mathrm{~h}$, daily, for 30 days. Seedlings were transplanted to pots filled with $1.5 \mathrm{~L}$ of substrate (Carolina Soil do Brasil) amended with the following ammonium nitrate doses: 0, 50, 100, 200 or 400 mg.L-1.

The experiment was carried out in a randomized design, following a $5 \times 3+1$ factorial design ( 5 doses of ammonium nitrate $\times 3$ biocontrol agents + additional treatment without ammonium nitrate, antagonistic agents and $S$. rolfsii), with 3 replicates (6 plants each).

Biocontrol agents Ônix (B. methylotrophicus) and Quality (T. asperellum) were inoculated through Pasteur pipette right after transplantation. The applied doses were proportional to the recommended ones: $3 \mathrm{~mL}$ of Ônix or $2 \mathrm{~mL}$ of Quality inoculated into $100 \mathrm{~kg}$ of seeds. Five days after seedling transplantation, S. rolfsii was inoculated with $8 \mathrm{~g}$ of colonized rice per liter of substrate.

Plant mortality was assessed when the tomato plants inoculated with $S$. rolfsii started presenting the symptoms. The assessment was carried out daily for 10 days. Subsequently, plants were removed from substrate and sectioned to assess the following variables: shoot fresh weight (SFW) and root fresh weight (RFW); shoot dry weight (SDW) and root dry weight (RDW).

\section{Statistical analysis}

Colony diameters measured in vitro were subjected to t-test at $5 \%$ significance level with 10 replications. The resulting variables were subjected to variance analysis, Bartlett's test for homogeneity of variance. Contrasts of interest were performed by applying the Scheffé test $(\mathrm{p}<0.05)$ as follows: not inoculated $\times(B$. methylotrophicus + without biocontrol + T. asperellum); without biocontrol $\times(B$. methylotrophicus + T. asperellum $) ; B$. methylotrophicus $\times$ T. asperellum. Plant weight data were transformed through square $\operatorname{root}(\sqrt{x})$, whereas mortality was transformed through arcsine square root $\left(\sin ^{-1} \sqrt{x}\right)$. Statistical analyses were performed using SAS 9.1 software (SAS Institute Inc. Cary, NC, USA).

\section{RESULTS AND DISCUSSION}

Bacillus methylotrophicus and T. asperellum (antagonistic microorganisms) were effective in reducing mycelial growth of $S$. rolfsii during tests of parallel growing and metabolites antagonism assessment in vitro $(\mathrm{p}<0.001)$. Treatments without biological control were also not colonized by Trichoderma and/or Bacillus. Thus, cross-contamination between treatments and replications was disregarded.

Bacillus methylotrophicus reduced the mycelial growth of $S$. rolfsii by $32 \%$, classified as grade 3 antagonism (Fig. 1). Genus Bacillus produced substances such as fengycin, iturin and surfactin (BAIS et al., 2004; CHUNG et al., 2015; CRANE et al., 2013; MCLEAN; STEWART, 2000) with fungicidal ability to inhibit pathogen growth (FUGA et al., 2011; STEIN, 2005). Therefore, this inhibition is assumingly induced by antibiosis.
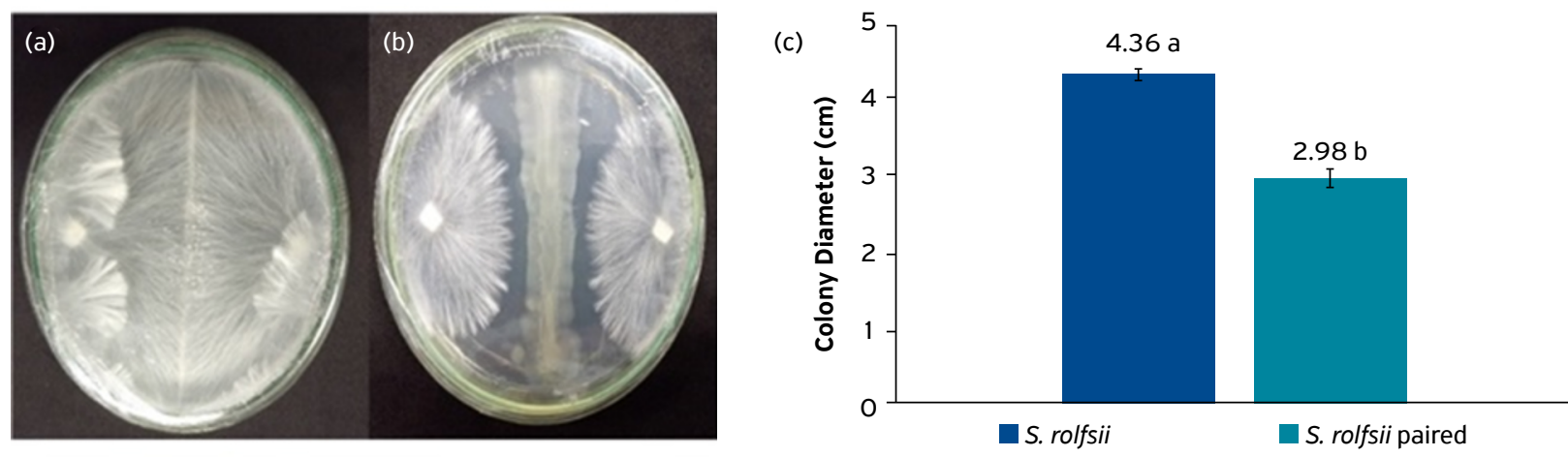

Figure 1. Inhibitory activity of B. methylotrophicus against S. rolfsii 2 days after incubation. (a) S. rolfsii; (b) paired S. rolfsii; (c) colony diameters. Means followed by the same letter were not significantly different at $p<0.0001$ in the $t$-test. Bars represent mean standard error. Growth inhibition $=32 \%$. 
Trichoderma asperellum reduced mycelial growth of $S$. rolfsii by $14 \%$ when they were paired together. This rate was classified as grade 4 antagonism (Fig. 2). ROCHA et al. (2016) found that T. asperellum isolates inoculated in Quality showed decreased growth against high toxin-producing Fusarium solani isolates, which could suggest limiting factors to Quality dose for soilborne pathogen control.

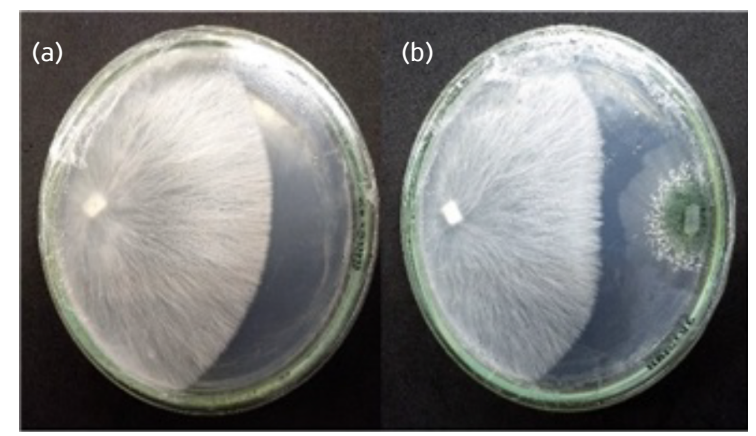

(c)

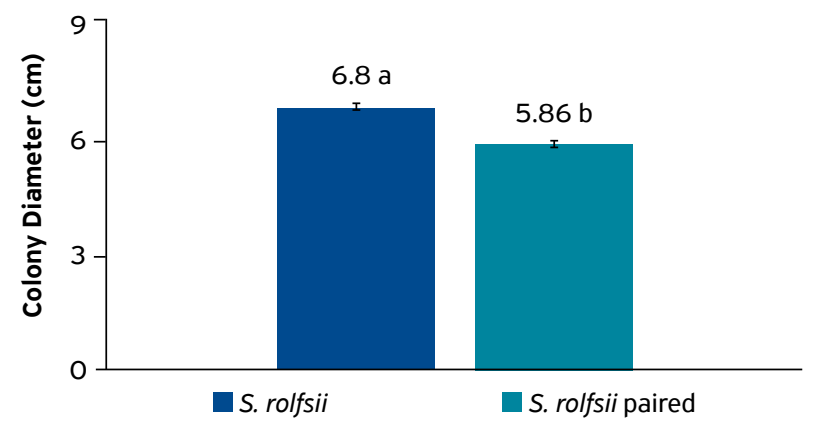

Figure 2. Mycelial growth of S. rolfsii paired with T. asperellum 3 days after incubation. (a) S. rolfsii; (b) paired S. rolfsii; (c) colony diameters. Means followed by the same letter were not significantly different in the t-test. Bars represent mean standard error. Growth inhibition $=13.8 \%$.

The sensitivity of $S$. rolfsii to metabolites secreted by T. asperellum has shown that nonvolatile metabolites reduced the mycelial growth of S. rolfsii by approximately $57 \%$ (Fig. 3), whereas volatile metabolites reduced it by approximately $40 \%$ (Fig. 4). These rates were classified as grade 3 and 4 antagonisms, respectively. Data indicated that the secretion of toxic antifungal metabolites was the most effective biocontrol response of T. asperellum against S. rolfsii. Although Trichoderma species are associated with antibiosis through mycoparasitism - colonization and degradation of hyphae and pathogen resistance structures (BENÍTEZ et al., 2004; BONTEMPO, 2016) - their key mechanism against some fungal species and isolates is the secretion of toxic metabolites, as the case of T. asperellum.
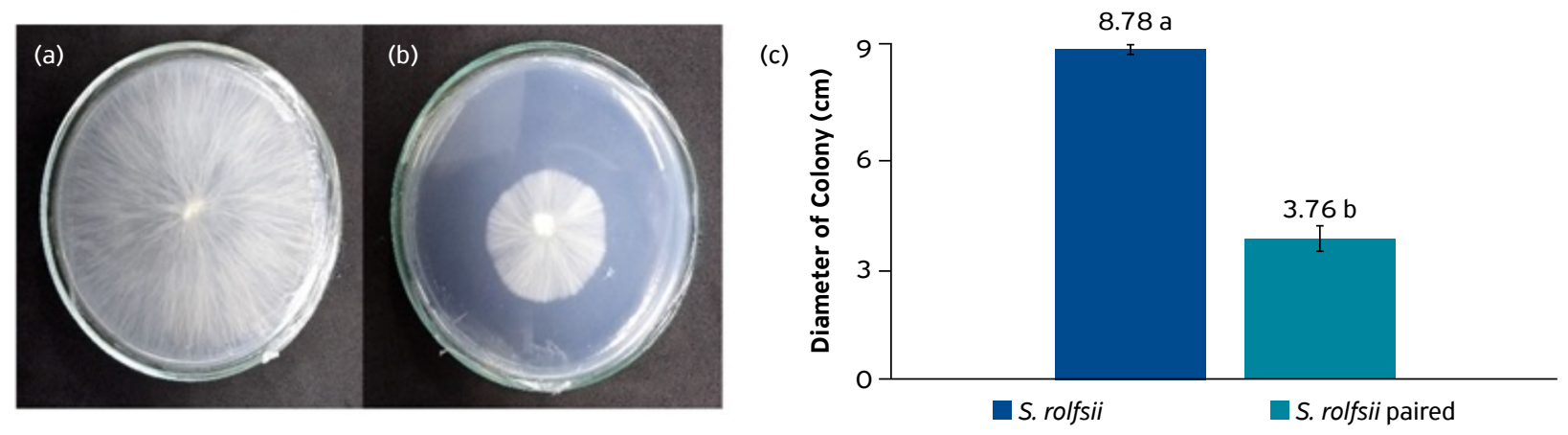

Figure 3. Mycelial growth of $S$. rolfsii under antibiosis against T. asperellum's nonvolatile metabolites 2 days after incubation. (a) S. rolfsii; (b) S. rolfsii under antibiosis; (c) t-test. Different letters indicate different values in the t test ( $<<0.0001)$. Bars represent mean standard error. Growth inhibition $=57 \%$.
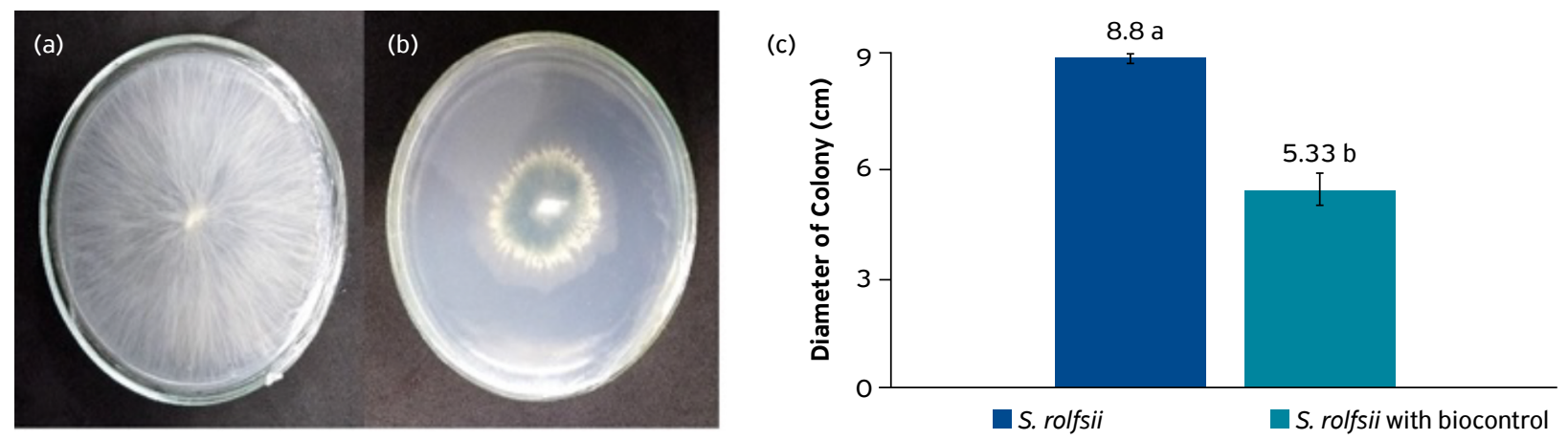

Figure 4. Mycelial growth of S. rolfsii under antibiosis against T. asperellum's volatile metabolites 2 days after incubation. (a) S. rolfsii; (b) Antagonized S. rolfsii; (c) Diameter of S. rolfsii colonies. Different letters indicate statistically different values in the t test $(p<0.0001)$. Bars represent mean standard error. Growth inhibition $=39.5 \%$. 
Biocontrol agents had no effect on tomato plant mortality 11 days after inoculation with $S$. rolfsii (Fig. 5), according to the $\mathrm{F}$ test $(\mathrm{p}=0.1550)$. Ammonium nitrate doses did not reduce tomato plant mortality (Fig. 5$)$ in the $\mathrm{F}$ test $(\mathrm{p}=0.5228)$.
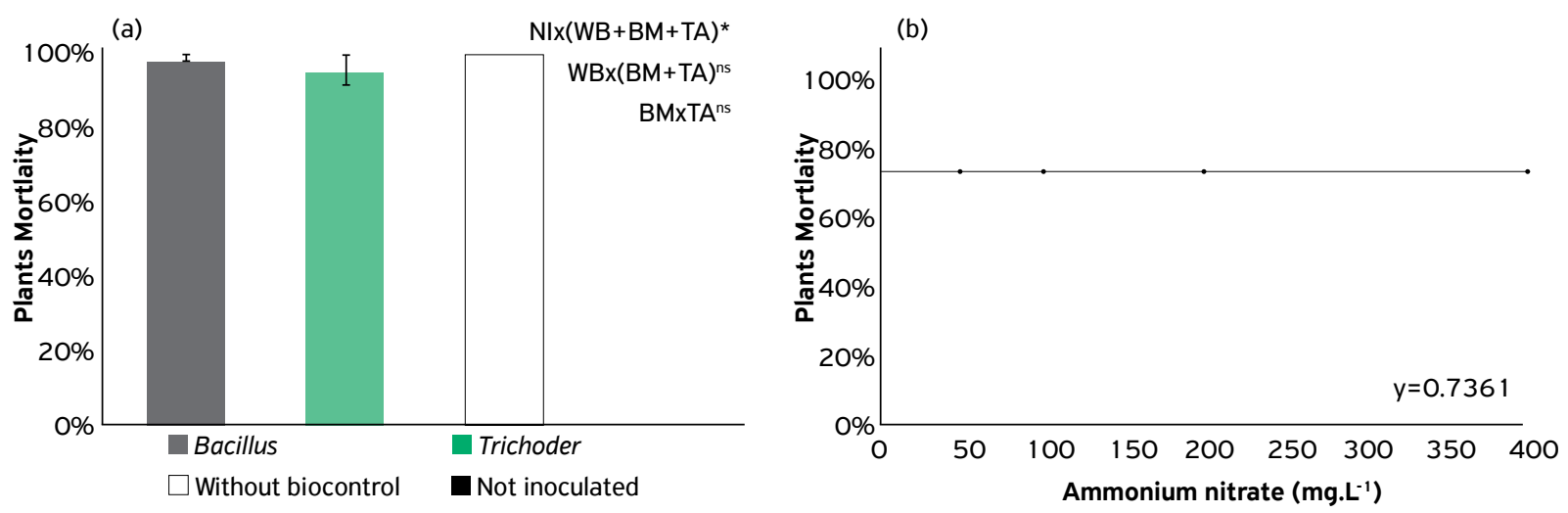

Figure 5. Mortality of tomato plants 11 days after inoculation with S. rolfsii: (a) by different biocontrol agents and (b) under ammonium nitrate doses. Bars represent mean standard error; ${ }^{\text {ns: }}$ not significant at $5 \%$ in the Scheffé's test; ${ }^{*}$ : significant at $5 \%$ in the Scheffé's test. Bacillus methylotrophicus (BM); T. asperellum (TA); without biocontrol (SB); not inoculated (TT).

Although the genus Trichoderma is acknowledged as a soilborne biocontrol agent, it was not effective against S. rolfsii. This inefficiency could be caused by variations on type and amount of toxic secondary metabolites among Trichoderma species and even isolates (MARTINS-CORDER; MELO, 1998). These variations cause biocontrol effectiveness to vary by up to 95\% (ROSA; HERRERA, 2009). Nevertheless, Trichoderma spp. efficacy in soilborne pathogen biocontrol still depends on critical factors, such as mycelial growth speed (SERRA; SILVA, 2005), ability to compete for nutrients and high sensitivity to environmental extremes (ETHUR et al., 2005). Experiments in vivo showed that competitors can reduce the inhibitory activity of Trichoderma sp. against Sclerotinia sclerotiorum in cucumber (ETHUR et al., 2005).

Root dry weight was affected by biocontrol agent's inoculation $(\mathrm{p}<0.05)$ (Fig. 6$)$ and nitrogen doses were only effective for shoot dry biomass (Fig. 7). However, the data did not suggest suppressiveness, the higher biomass values could be attributed only to nitrogen fertilization (CARDOSO; USTULIN FILHO, 2013).
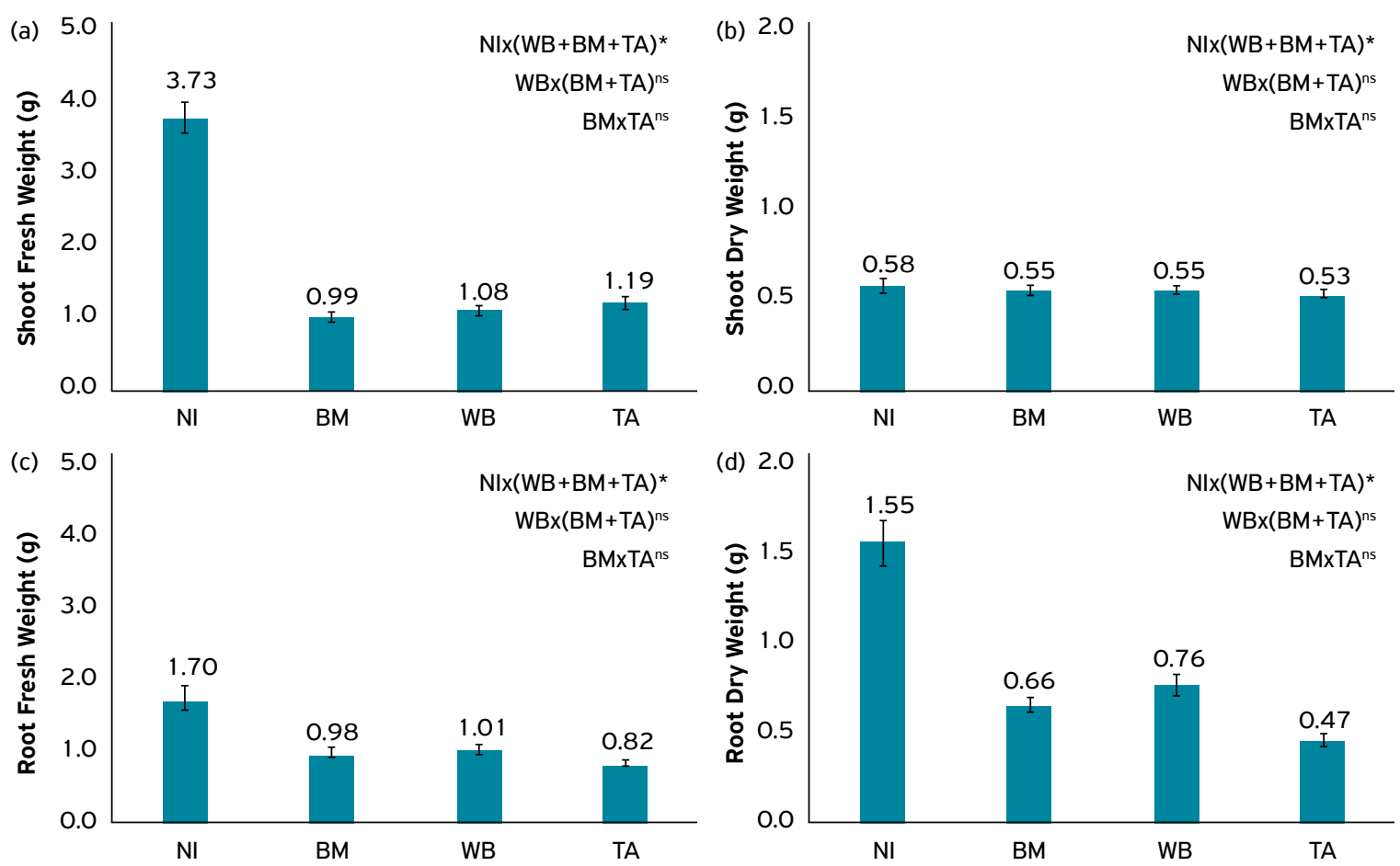

Figure 6. Variables above-ground Fresh (a) and dry (b) biomass; variables fresh (c) and dry (d) weight of tomato plant roots inoculated with S. rolfsii based on the following classifications: not inoculated, B. methylotrophicus, without biocontrol and T. asperellum. Bars represent mean standard error; ${ }^{\text {ns: }}$ not significant at $5 \%$ in the Scheffé's test; *: significant at $5 \%$ in the Scheffé's test. Bacillus methylotrophicus (BM); T. asperellum (TA); without biocontrol (SB); not inoculated (TT). 

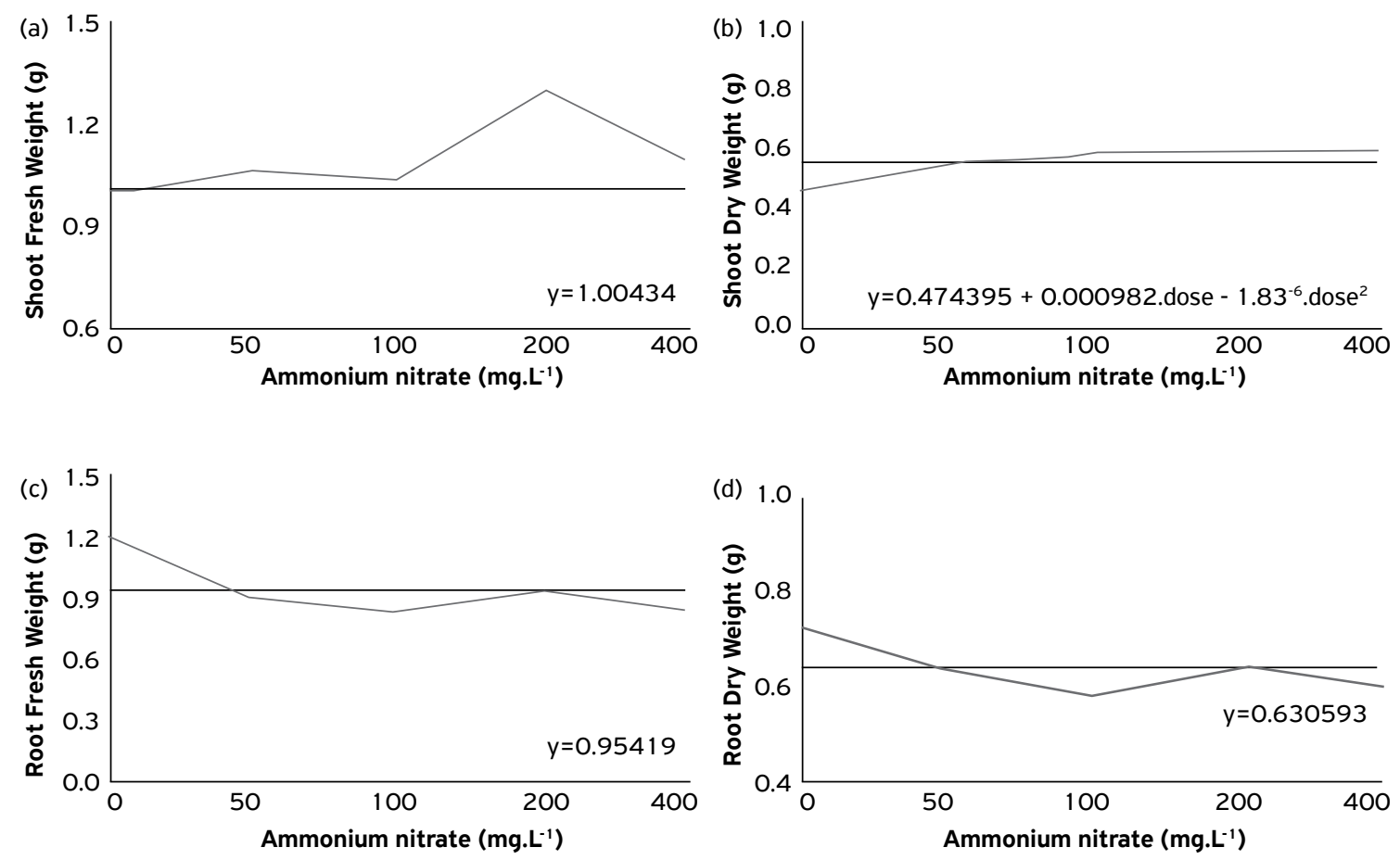

Figure 7. Regression adjustment of above-ground fresh (a) and dry (b) weight; regression adjustment of fresh (c) and dry (d) weight of tomato plant roots inoculated with S. rolfsii in agar added with different ammonium nitrate doses.

Root dry weight recorded higher values when tomato plants were treated with B. methylotrophicus, this finding suggests an inhibitory activity of these bacteria against $S$. rolfsii. On the other hand, B. methylotrophicus had no effect on shoot weight of tomato plants, which indicates that it does not promote plant growth, but produces antifungal metabolites or competes for nutrients (antibiosis) as biocontrol response (ALABOUVETTE et al., 2009; CHUNG et al., 2015). Moreover, plants inoculated with antagonistic Bacillus species may develop the ability to inhibit oxidative stress and to reduce disease severity (HASHEM et al., 2017), this reaction must be further studied on tomato southern blight.

Although bacteria belonging to the genus Bacillus have biocontrol ability (CHUNG et al., 2015), tomato plants mortality was not reduced by B. metylotrophicus. Biocontrol efficacy could have been impaired by other factors, such as bacterial population density, specific bacterial activity and application method (ABDALLA et al., 2014). Experiments in vivo carried out with Bacillus sp. demonstrated that the inoculation of this species in the soil reduced charcoal rot (Macrophomina sp.) severity in strawberry plants by $10 \%$. On the other hand, when it was inoculated straight into their roots, disease severity was reduced by $30 \%$ (PASTRANA et al., 2016). Moreover, Bacillus spp. applied as seed treatment presented up to $93 \%$ reduction in root rot of mustard seeds inoculated with S. sclerotiorum (MORETINI; MELO, 2007). Even though Bacillus has several action mechanisms for plant protection, research results suggested that it is more effective when inoculated straight into plant tissue, rather than just in the soil.

\section{CONCLUSIONS}

Data has shown that biocontrol agents assessed in vitro have inhibitory activity against $S$. rolfsii growth. Biocontrol helped to mitigate southern blight severity when it was combined with nitrogen fertilization. Nevertheless, the tested biocontrol agents, when combined with ammonium nitrate, did not control southern blight. Hence, further research must be carried out on the following: biocontrol application methods; the association of biocontrol agents with alternative management measures; inhibitory activity in vivo of different Bacillus and/or Trichoderma species and isolates against $S$. rolfsii. 


\section{AUTHORS' CONTRIBUTIONS}

Conceptualization: Graichen, F.A.S.; Blanco, N.H.M. Methodology: Graichen, F.A.S.; Blanco, N.H.M. Formal Analysis: Graichen, F.A.S.; Blanco, N.H.M. Visualization: Graichen, F.A.S.; Blanco, N.H.M. Investigation: Blanco, N.H.M.; Barbosa, D.F.R. Writing original draft: Blanco, N.H.M.; Barbosa, D.F.R.; Graichen, F.A.S. Writing - review \& editing: Blanco, N.H.M.; Graichen, F.A.S. Supervision: Graichen, F.A.S.

\section{AVAILABILITY OF DATA AND MATERIAL}

The datasets generated and/or analyzed during the current study are available from the corresponding author on reasonable request.

\section{FUNDING}

Coordenação de Aperfeiçoamento de Pessoal de Nível Superior

http://doi.org/10.13039/501100002322

Finance Code 001

Universidade Estadual de Mato Grosso do Sul/FUNDECT

Process 59/300.274/2016 - SIAFEM 26112

\section{CONFLICTS OF INTEREST}

All authors declare that they have no conflict of interest.

ETHICAL APPROVAL

Not applicable.

\section{ACKNOWLEDGEMENTS}

The authors thank to Coordenação de Aperfeiçoamento de Pessoal de Nível Superior (CAPES) for granting a scholarship to the first author.

\section{REFERENCES}

ABDALLA, S.A.; ALGAM, S.A.A.; IBRAHIM, E.A.; EL NAIM, A.M. In Vitro Screening of Bacillus Isolates for Biological Control of Early Blight Disease of Tomato in Shambat Soil. World Journal of Agricultural Research, Newark, v.2, n.2., p.47-50, 2014. https://doi. org/10.12691/wjar-2-2-3

ALABOUVETTE, C.; OLIVAIN, C.; MIGHELI, Q.; STEINBERG, C. Microbiological control of soil-borne phytopathogenic fungi with special emphasis on wilt-inducing Fusarium oxysporum. New Phytologist, Lancashire, v.184, n.3, p.529-544, 2009. https://doi. $\operatorname{org} / 10.1111 / j .1469-8137.2009 .03014 . x$

BAIS, H.P.; FALL, R.; VIVANCO, J.M. Biocontrol of Bacillus subtilis against infection of Arabidopsis Roots by Pseudomonas syringae Is Facilitated by Biofilm Formation and Surfactin Production. Plant Physiology, Rockville, v.134, n.1, p.307-319, 2004. https://oi.org/10.1104/ pp.103.028712

BARAKAT, R.M.; AL-MAHAREEQ, F.; AL-MASRI, M.I. Biological Control of Sclerotium rolfsii by Using Indigenous Trichoderma spp. Isolates from Palestine. Hebron University Research Journal, Hebron, v.2, n.1, p.27-47, 2005. Available from: https://digitalcommons.aaru. edu.jo/hujr_a/vol2/iss2/2/. Access on: 09 Nov. 2020.

BELL, D.K.; WELLS, H.D.; MARKHAM, C.R. In Vitro Antagonism of Trichoderma SPECIES Against Six Fungal Plant Pathogens. Ecology and Epidemiology, Saint Paul, v.72, n.4, p.379-382, 1982. https://doi.org/10.1094/Phyto-72-379

BENÍTEZ, T.; RINCÓN, A.M.; LIMÓN, M.C.; CODÓN, A.C. Biocontrol mechanisms of Trichoderma strains. International Microbiology, Barcelona, v.7, n.4, p.249-260, 2004. Available from: http://scielo.isciii.es/scielo.php?script=sci_abstract\&pid=S1139-67092004000400003\&lng =es\&nrm=iso\&tlng=en. Access on: 9 Nov. 2020.

BONTEMPO, A.F. Seleção "in vitro" de isolados de Trichoderma spp. e Bacillus spp. em baixa temperatura de crescimento para o controle de Sclerotium cepivorum. 2016. Dissertation (Master in Agronomy - Plant Production) - Universidade Federal de Viçosa, Rio Paranaíba, 2016. 
BROŽOVÁ, J. Mycoparasitic fungi Trichoderma spp. in plant protection - Review. Plant Protection Science, Prague, v.40, n.2, p.63-74, 2004. https://doi.org/10.17221/459-PPS

CARDOSO, A.I.I.; USTULIN FILHO, A.J. Produção de chicória em função de doses de nitrogênio e potássio aplicadas na fase de mudas. Horticultura Brasileira, Brasília, v.31, n.4, p.654-658, 2013. https://doi.org/10.1590/S0102-05362013000400024

CARVALHO, D.D.C.; LOBO JUNIOR, M.; MARTINS, I.; INGLIS, P.W.; MELLO, S.C.M. Biological control of Fusarium oxysporum f. sp. phaseoli by Trichoderma harzianum and its use for common bean seed treatment. Tropical Plant Pathology, Viçosa, v.39, n.5, p.384-391, 2014. https://doi.org/10.1590/S1982-56762014000500005

CHUNG, E.J.; HOSSAIN, M.T.; KHAN, A.; KIM, K.H.; JEON, C.O.; CHUNG, Y.R. Bacillus oryzicola sp. nov, an endophytic bacterium isolated from the roots of rice with antimicrobial, plant growth promoting, and systemic resistance inducing activities in rice. The Plant Pathology Journal, Daejeon, v.31, n.2, p.152-164, 2015. https://doi.org/10.5423/PPJ.OA.12.2014.0136

CRANE, J.M.; GIBSON, D.M.; VAUGHAN, R.H.; BERGSTROM, G.C. Iturin levels on wheat spikes linked to biological control of fusarium head blight by Bacillus amyloliquefaciens. Phytopathology, Saint Paul, v.103, n.2, p.146-155, 2013. https://doi.org/10.1094/ PHYTO-07-12-0154-R

CRUZ, S.M.C.; RODRIGUES, A.A.C.; SILVA, E.K.C.; OLIVEIRA, L.J.M.G. Supressividade por incorporação de resíduo de leguminosas no controle da fusariose do tomateiro. Summa Phytopathologica, Botucatu, v.39, n.3, p.180-185, 2013. https://doi.org/10.1590/ S0100-54052013000300006

DENNIS, C.; WEBSTER, J. Antagonistic properties of species-groups of Trichoderma II. Production of volatile antibiotics. Transactions of the British Mycological Society, London, v.57, n.1, p.41-48, 1971. https://doi.org/10.1016/S0007-1536(71)80078-5

DIMKIĆ, I.; ŽIVKOVIĆ, S.; BERIĆ, T.; IVANOVIĆ, Ž.; GAVRILOVIĆ, V.; STANKOVIĆ, S.; FIRA, D. Characterization and evaluation of two Bacillus strains, SS-12.6 and SS-13.1, as potential agents for the control of phytopathogenic bacteria and fungi. Biological Control, Sophia Antipolis, v.65, n.3, p.312-321, 2013. https://doi.org/10.1016/j.biocontrol.2013.03.012

ETHUR, L.Z.; BLUME, E.; MUNIZ, M.; SILVA, A.C.F.; STEFANELO, D.R.; ROCHA, E.K. Fungos antagonistas a Sclerotinia sclerotiorum em pepineiro cultivado em estufa. Fitopatologia Brasileira, Brasília, v.30, n.2, p.127-133, 2005. https://doi.org/10.1590/S0100-41582005000200004

FUGA, C.A.G.; GONÇALVES, D.C.; CUNHA, W.V. Inibição do crescimento micelial de Colletotrichum gloeosporioides por Bacillus spp. "in vitro". Revista Perquirere, Patos de Minas, v.1, n.8, p.188-194, 2011.

GHINI, R.; BETTIOL, W.; DYNIA, J.F.; MAIA, A.H.N. Efeito de adubos nitrogenados na supressividade de solos a fitopatógenos. Revista Ecossistema, Espírito Santo do Pinhal, v.26, n.2, p.147-151, 2001. Available from: http://ferramentas.unipinhal.edu.br/ecossistema/ viewarticle.php?id=39\&layout=abstract. Access on: 9 Nov. 2020.

HASHEM, A.; ABD-ALLAH, E.F.; ALQARAWI, A.A.; RADHAKRISHNAN, R.; KUMAR, A. Plant defense approach of Bacillus subtilis (BERA 71) against Macrophomina phaseolina (Tassi) Goid in mung bean. Journal of Plant Interactions, Turin, v.12, n.1, p.390-401, 2017. https://doi.org/10.1080/17429145.2017.1373871

MARTINS-CORDER, M.P.; MELO, I.S. Antagonismo in vitro de Trichoderma spp. A Verticillium dahliae Kleb. Scientia Agricola, Piracicaba, v.55, n.1, p.1-7, 1998. https://doi.org/10.1590/S0103-90161998000100002

MCLEAN, K.L.; STEWART, A. Application strategies for control of onion white rot by fungal antagonists. New Zealand Journal of Crop and Horticultural Science, Auckland, v.28, n.2, p.115-122, 2000. https://doi.org/10.1080/01140671.2000.9514131

MELERO-VARA, J.M.; PRADOS-LIGERO, A.M.; BASALlOTE-UREBA, M.J. Comparison of Physical, Chemical and Biological Methods of Controlling Garlic White rot. European Journal of Plant Pathology, London, v.106, n.6, p.581-588, 2000. https://doi. org/10.1023/A:1008777706814

MORETINI, A.; MELO, I.S. Formulação do fungo Coniothyrium minitans para controle do mofo-branco causado por Sclerotinia sclerotiorum. Pesquisa Agropecuária Brasileira, Brasília, v.42, n.2, p.155-161, 2007. 
MORI, M. Efeito do pH e de diferentes fontes de N na supressão de Sclerotium rolfsii em tomateiro. 44p. Dissertation (Masters in Agronomy) - Universidade Estadual de Mato Grosso do Sul, Aquidauana, 2015.

PACHECO, K.R. Avaliação de Trichoderma e de fosfito no controle de Sclerotium rolfsii agente da murcha-de-esclerócio em feijoeiro. 75p. Dissertation (Masters in Agronomy) - Universidade de Brasília, Brasília, 2012.

PALOP, A.; MAÑAS, P.; CONDÓN, S. Sporulation temperature and heat resistance of Bacillus spores: a review. Journal of Food Safety, Albany, v.19, n.1, p.57-72, 1999. https://doi.org/10.1111/j.1745-4565.1999.tb00234.x

PASTRANA, A.M.; BASALLOTE-UREBA, M.J.; AGUADO, A.; AKDI, K.; CAPOTE, N. Biological control of strawberry soilborne pathogens Macrophomina phaseolina and Fusarium solani, using Trichoderma asperellum and Bacillus spp. Phytopathologia Mediterranea, Florence, v.55, n.1, p.109-120, 2016. Available from: https://core.ac.uk/download/pdf/228522213.pdf. Access on: 9 Nov. 2020.

PUNJA, Z.K. The Biology, Ecology and Control of Sclerotium rolfsii. Annual Review of Phytopathology, Palo Alto, v.23, p.97-127, 1985. https://doi.org/10.1146/annurev.py.23.090185.000525

RISTAINO, J.B.; PERRY, K.B.; LUMSDEN, R.D. Effect of solarization and Gliocladium virens on sclerotia of Sclerotium rolfsii, soil microbiota, and the incidence of Southern Blight of tomato. Phytopathology, Saint Paul, v.81, n.10, p.1117-1124, 1991. https://doi. org/10.1094/Phyto-81-1117

ROCHA, F.S.; FERREIRA, G.H.S.; SILVA, T.C.S.R.; AMARAL, F.L.; MUNIZ, M.F.S.; PEREIRA, E.A. Caracterização de Fusarium solani f. sp. piperis, produção de fitotoxina e incidência da fusariose no norte de Minas Gerais. Summa Phytopathologica, Botucatu, v.42, n.1, p.67-72, 2016. https://doi.org/10.1590/0100-5405/2100

ROSA, D.R.; HERRERA, C.J.L. Evaluation of Trichoderma spp. as biocontrol agents against avocado white root rot. Biological Control, Sophia Antipolis, v.51, n.1, p.66-71, 2009. https://doi.org/10.1016/j.biocontrol.2009.05.005

ROSE, S.; PARKER, M.; PUNJA, Z.K. Efficacy of biological and chemical treatments for control of fusarium root and stem rot on greenhouse cucumber. Plant Disease, Saint Paul, v.87, n.12, p.1462-1470, 2003. https://doi.org/10.1094/PDIS.2003.87.12.1462

SARMA, B.K.; SINGH, U.P.; SINGH, K.P. Variability in Indian isolates of Sclerotium rolfsii. Mycologia, College Park, v.94, n.6, p.1051-1058, 2002. https://doi.org/10.1080/15572536.2003.11833160

SERRA, I.M.R.S.; SILVA, G.S. Caracterização biológica e fisiológica de isolados de Sclerotium rolfsii obtidos de pimentão no Estado do Maranhão. Fitopatologia Brasileira, Brasília, v.30, n.1, p.61-66, 2005. https://doi.org/10.1590/S0100-41582005000100010

STEIN, T. Bacillus subtilis antibiotics: structures, syntheses and specific functions. Molecular Microbiology, Ithaca, v.56, n.4, p.845-857, 2005. https://doi.org/10.1111/j.1365-2958.2005.04587.x

VILLALTA, O.N.; WITE, D.; PORTER, I.J.; MCLEAN, K.L.; STEWART, A.; HUNT, J. Integrated control of onion white rot on spring onions using diallyl disulphide, fungicides and biocontrols. Acta Horticulturae, Hague, v.944, n.1, p.63-71, 2012. https://doi.org/10.17660/ ActaHortic.2012.944.8 